\title{
Macrofauna - plant-biomass interactions in a euhaline salt marsh in Paranaguá Bay (SE Brazil)
}

\author{
Paulo da Cunha Lana, Claudia Guiss
}

Centro de Biologia Marinha, Universidade Federal do Paraná, 83200 Pontal do Sul, Paraná, Brazil

\begin{abstract}
To assess if benthic macrofaunal parameters correlate with above- and below-ground plant biomass, we conducted a 14 mo survey over an intertidal flat colonized by Spartina alterniflora in the euhaline, high-energy sector of Paranaguá Bay (Southeastern Brazil). Variations in species richness, overall abundance of epifauna and infauna, and densities of numerically dominant species in relation to Spartina biomass values were analyzed using principal components analysis and stepwise multiple regression. Ninety-eight taxa were found, with the 9 most abundant species comprising more than $80 \%$ of total macrofauna. A 2-factor principal component model, which explained $65.7 \%$ of the total variation within the data set, revealed a strong interaction among plant biomass values, faunal parameters and time of year, as well as an inverse relationship between aerial and below-ground plant components, reflecting storage and growth events. Variation in total numbers of species and densities of the epifaunal Parhyalella whelpleyi (Amphipoda) and Bittium varium (Gastropoda), and the infaunal Lucina pectinata (Bivalvia) was not significantly related to the various plant biomass measures, suggesting that other processes may be involved in the regulation of local species richness. On the other hand, total infaunal numbers, and the densities of the infaunal dominants, Isolda pulchella and Nereis oligohalina (Polychaeta), were significantly predicted by live below-ground biomass expressed as dry weight, but not as ash-free dry weight. This indicates that plant material is primarily used as a refuge or physical support to tubes, rather than as a food source. Total epifaunal and Littorina flava (Gastropoda) numbers were negatively correlated to live above-ground plant biomass. We advance some hypotheses to explain such an unexpected pattern, taking into account feeding strategies and predation pressure as influenced by plant characteristics. We infer that infaunal abundance is in fact strongly affected by below ground Spartina biomass. Unexpectedly, higher aerial plant biomass did not bear higher epifaunal or infaunal numbers; such relationships would be better expressed by negative linear interactions or nonlinear models. Plant architecture is a major force, together with seasonal oscillations in detrital input and predation pressure, in structuring the macrofauna of local salt marshes.
\end{abstract}

\section{INTRODUCTION}

The presence of plant substratum influences species composition and abundance of invertebrate fauna in many marine habitats, such as subtidal seagrass meadows and intertidal salt marshes. Plant structures may reduce the densities of some species and enhance others (Orth et al. 1984, Decho et al. 1985, Capehart \& Hackney 1989). A number of mechanisms have been proposed to explain patterns of faunal variability in marine vegetated areas, including habitat complexity, protection from predation, food availability, changes in hydrodynamic conditions, sediment stability, and soil oxygenation (Daiber 1982, Fonseca et al. 1982, Kneib 1984, Orth et al. 1984, Lin 1989). However, plant structures vary considerably. Marine plants exhibit a variety of leaf shapes and lengths and shoot densities, as well as of depths and thickness of the root and rhizome layer. Moreover vegetated habitats can display varying degrees of complexity even within relatively small areas (Heck 1977). A similar mechanism may have positive or negative effects on macrobenthic populations in different habitats, depending on the architecture of the plant or formation. It is not surprising that consistent paradigms or generalizations concerning faunal regulation in marine vegetated environments have not yet arisen in the ecological literature.

Salt marsh habitats, widespread in protected tidal flats of temperate and subtropical estuaries, are presumed to play an important role in the productivity of adjacent waters as nursery grounds for species of 
economic value or as detritus exporters. In temperate regions, salt marshes are structurally complex systems composed of an array of macrophytic vegetation (Long \& Mason 1983). Processes which influence the distribution and abundance of salt marsh invertebrate fauna have been mainly investigated along the Atlantic coasts of the USA and Europe (Ranwell 1972, Daiber 1982, Kneib 1984). In contrast, tropical or subtropical salt marshes of the southern hemisphere, associated with or even outcompeted by mangrove woodland, are less developed, Iess diversified, and have received less attention in literature.

The grass Spartina alterniflora Loisel is the dominant and pioneer species in salt marshes along the Brazilian southeast coast. It usually colonizes tidal flats or creeks as narrow discontinuous bands in front of mangroves. The regional literature concerning the phenology, production, decomposition, and nutrient cycling of $S$. alterniflora has been listed by Lana et al. (1991). The invertebrate or demersal fauna of local salt marshes have been investigated by Gerlach (1958), Capitoli et al. (1977, 1978), Bemvenuti (1987), Tararam \& Wakabara (1987), Takeda (1988) and Lana \& Guiss (1991). However, little is known about the small-scale effects of the major structural features of tidal marshes, e.g. the plant culms, roots and rhizomes themselves.

In this study, carried out in a euhaline, high-energy, subtropical salt marsh in Paranagua' Bay (SE Brazil), we: (1) investigated whether macrobenthic species richness and abundance correlate with above- and below-ground biomass of Spartina altemiflora, and (2) hypothesize about the importance of Spartina in determining the distribution and abundance patterns of associated macrofauna.

\section{MATERIALS AND METHODS}

The research was conducted $500 \mathrm{~m}$ northeast of Baguaçu tidal creek ( $25^{\circ} 33^{\prime} 00^{\prime \prime} \mathrm{S}, 48^{\circ} 23^{\prime} 30^{\prime \prime} \mathrm{W}$ ), in the high-energy, euhaline sector of Paranagua' Bay, a semi-enclosed estuarine system bounded by mangroves and salt marshes (Fig. 1). The specific study site was a pristine monospecific stand of Spartina alterniflora ca 15 to $20 \mathrm{~m}$ wide and $300 \mathrm{~m}$ long. General accounts of the local flora and fauna have been previously provided by Lana et al. (1991) and Lana \& Guiss (1991). S. alterniflora plants of the local population reach a maximum height of $120 \mathrm{~cm}$ during the summer growing season. Local tides are characterized by diurnal inequality and approach a semi-diurnal pattern at maximum tidal amplitudes (ca $2 \mathrm{~m}$ ); surface currents can attain velocities between 100 and $125 \mathrm{~cm}$ $\mathrm{s}^{-1}$ (Knoppers et al. 1987). Salinity ordinarily ranges from $28 \%$ to $31 \%$, with lower values, down to $23.5 \%$,

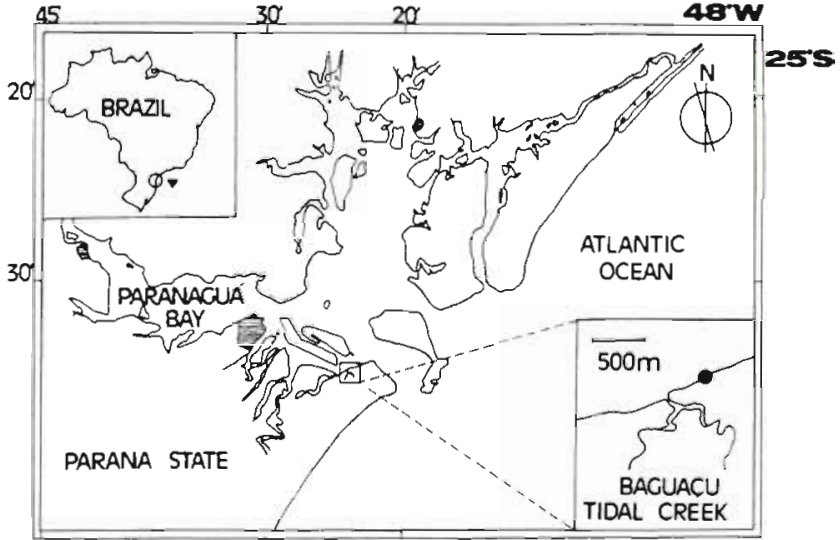

Fig. 1. Paranaguá Bay showing the location of the study site near Baguaçu tidal creek

during heavy rainfall. Sediment temperature ranges from $19^{\circ} \mathrm{C}$ in the winter to $34^{\circ} \mathrm{C}$ in the summer. The sediment is a mixture of sand and silt-clay ( 7 to $18 \%$ ); mean grain size lies between 2.69 and $3.13(\varnothing)$, and organic carbon accounts tor 0.9 to $3.3 \%$ of the sediment dry weight (Lana \& Guiss 1991).

Plant biomass and macrofauna were sampled from May 1987 to June 1988. Sampling design took into account the homogeneity of Spartina cover, height and density to ensure adequate conditions for quadrat strategy. Five samples of $0.09 \mathrm{~m}^{2}(30 \mathrm{~cm}$ by $30 \mathrm{~cm}$, dug to a depth of $12 \mathrm{~cm}$ ), covering a total surface area of $0.45 \mathrm{~m}^{2}$, were randomly taken each month and pooled. Shoot or above-ground biomass was determined by clipping the vegetation at ground level; dead or partially decayed material, identified by the yellowish or brownish coloration, was separated from the living. Plant material, labeled live and dead, was dried to constant weight at 80 to $90^{\circ} \mathrm{C}$. Ash-free dry weight or organic content was calculated after burning subsamples of 1 to $2 \mathrm{~g}$ at $550^{\circ} \mathrm{C}$ for $90 \mathrm{~min}$. In order to determine living below-ground biomass, roots and rhizomes were washed out from the sediment; additional rooted material was also removed below the top $12 \mathrm{~cm}$ layer. The dead fraction was not quantified, since decaying below-ground material could not be easily separated from other soil detritus. Dry and ash-free dry weights of below-ground material were determined as above.

Epifauna were hand sorted from above-ground plant material, followed by a second sorting through a $0.5 \mathrm{~mm}$ mesh. Sediment samples were sieved through $1.0 \mathrm{~mm}$ and $0.5 \mathrm{~mm}$ meshes and below-ground plant material was carefully searched for associated macrofauna. The retained material was fixed in $10 \%$ neutral formalin, and preserved in $70 \%$ alcohol. The number of species per month ( $s)$, total epifaunal abundance, 
total infaunal abundance and the density of the numerically dominant species $\left(N\right.$, ind. $\left.0.45 \mathrm{~m}^{-2}\right)$ were recorded.

Log $(x+1)$ transformations were applied to reduce the heterogeneity of raw data for subsequent statistical or numerical analyses. The original data matrix included 18 variables (faunal parameters and plant biomass values) in each of 14 sampling months.

A simple correlation matrix was first calculated, using faunal and plant biomass parameters as variables. On the basis of the correlation analysis, multivariate techniques (stepwise multiple regression and principal components analysis) were then used to determine if faunal variation existed and if it could be associated with plant biomass variation.

Stepwise multiple regression was performed in order to describe and predict the relationship between variables. Linear models were hypothesized with total infauna, total epifauna, densities of numerically dominant species, and total number of species as dependent variables. Above- and below-ground biomass values, expressed as dry weight and ash-free dry weight, were assumed as predictor or independent variables. The possibility of first-order positive auto-correlation was tested by Durbin-Watson statistics at 0.01 level for all variables.

Principal components analysis (Legendre \& Legendre 1983) was employed to reduce the multivariate nature of the correlation matrix to a few interpretable dimensions. In factorial maps, variables were identified by 6-letter words (e.g. NER.VIR for Neritina virginea) and samplings by the month and year (87 or 88). Multivariate packages were developed by Dr Jean L. Valentin (Instituto de Estudos do Mar Almirante Paulo Moreira, Arraial do Cabo, Rio de Janeiro 28910, Brazil).

\section{RESULTS}

A total of 98 taxa were found, with the 9 most abundant species accounting for more than $80 \%$ of the total macrofauna. Faunal numbers and plant biomass values per $0.45 \mathrm{~m}^{2}$ are summarized in Table 1 . The gastropods Neritina virginea (coded NER.VIR for subsequent numerical analyses), Littorina flava (LIT.FLA) and Bittium varium (BIT.VAR), the isopod Sphaeromopsis mourei (SPH.MOU), and the amphipod Parhyalella whelpleyi (PAR.WHE) comprised $89.2 \pm$ $7.9 \%$ of the total epifauna (EPI.TOT). Epifauna averaged 230 ind. $0.45 \mathrm{~m}^{-2}$ and ranged from a minimum of 38 ind. in January 1988 to 389 ind. $0.45 \mathrm{~m}^{-2}$ in June 1987. The polychaetes Isolda pulchella (ISO.PUL) and Nereis oligohalina (NER.OLI), and the bivalves Lucina pectinata (LUC.PEC) and Sphenia antillensis
(SPH.ANT) comprised $78.3 \pm 20 \%$ of total infaunal numbers. The mean density of total infauna (INF.TOT) was 1414 ind. $0.45 \mathrm{~m}^{-2}$, ranging from 114 ind. $0.45 \mathrm{~m}^{-2}$ in March 1988 to 5103 ind. $0.45 \mathrm{~m}^{-2}$ in June 1987. The number of species (NUM.SPE), including epifaunal and infaunal species, varied from $290.45 \mathrm{~m}^{-2}$ in January 1988 to $440.45 \mathrm{~m}^{-2}$ in July 1987.

Live below-ground plant biomass (LBG.DRY for dry weight, and LBG.ASH for ash-free dry weight) was characterized by higher values than aerial biomass, ranging from $78 \mathrm{~g}$ dry wt $0.45 \mathrm{~m}^{-2}$ in late summer (March 1988) to $258.4 \mathrm{~g}$ dry wt $0.45 \mathrm{~m}^{-2}$ in late spring (November 1987). Biomass of live above-ground tissue (LAG.DRY for dry weight and LAG.ASH for ash-free dry weight) was usually higher than dead aboveground tissue (DAG.DRY for dry weight and DAG.ASH for ash-free dry weight), ranging from 23.2 g dry wt $0.45 \mathrm{~m}^{-2}$ in May 1988 to $52.7 \mathrm{~g}$ dry wt $0.45 \mathrm{~m}^{-2}$ in April 1988. Peak values of dead above-ground biomass, up to $37.1 \mathrm{~g}$ dry wt $0.45 \mathrm{~m}^{-2}$ in May 1987 , were usually recorded in late autumn and winter samples.

Values and statistical significance of correlation coefficients yielded by simple linear correlations between faunal parameters and plant biomass values are shown in Table 2. As expected, plant biomass values expressed as dry weight and ash-free dry weight were highly correlated $(r=0.80$ for below-ground biomass, $r=0.95$ for dead above-ground biomass and $r=0.98$ for live above-ground biomass). However, above- and below-ground biomass values of living tissues as ashfree dry weight were negatively correlated. Variation in infaunal abundance was most closely related to live below-ground biomass as dry weight $(\mathrm{r}=0.89)$. Variation in epifaunal numbers was negatively correlated with live above-ground biomass as ash-free dry weight ( $r=-0.54)$. The total number of species was not correlated with plant biomass.

Percent variation of the total number of species and densities of the epifaunal Parhyalella whelpleyi and Bittium varium on the various biomass measures was not statistically significant; no variables met statistical criteria and no prediction was possible with stepwise multiple regression (Table 3).

Total infaunal numbers and densities of the infaunal species Nereis oligohalina and Isolda pulchella were predicted by live below-ground biomass as dry weight $\left(\mathrm{R}^{2}>0.70, \mathrm{p}<0.01\right)$. In this case, live or dead aboveground biomass values were not significant factors and did not account for infaunal variation; thus, an expectation that higher aerial plant biomass would bear higher infaunal numbers was not supported.

Live above-ground plant biomass as ash-free dry weight (LAG.ASH) was the single most useful variable in predicting total epifaunal numbers and Littorina 

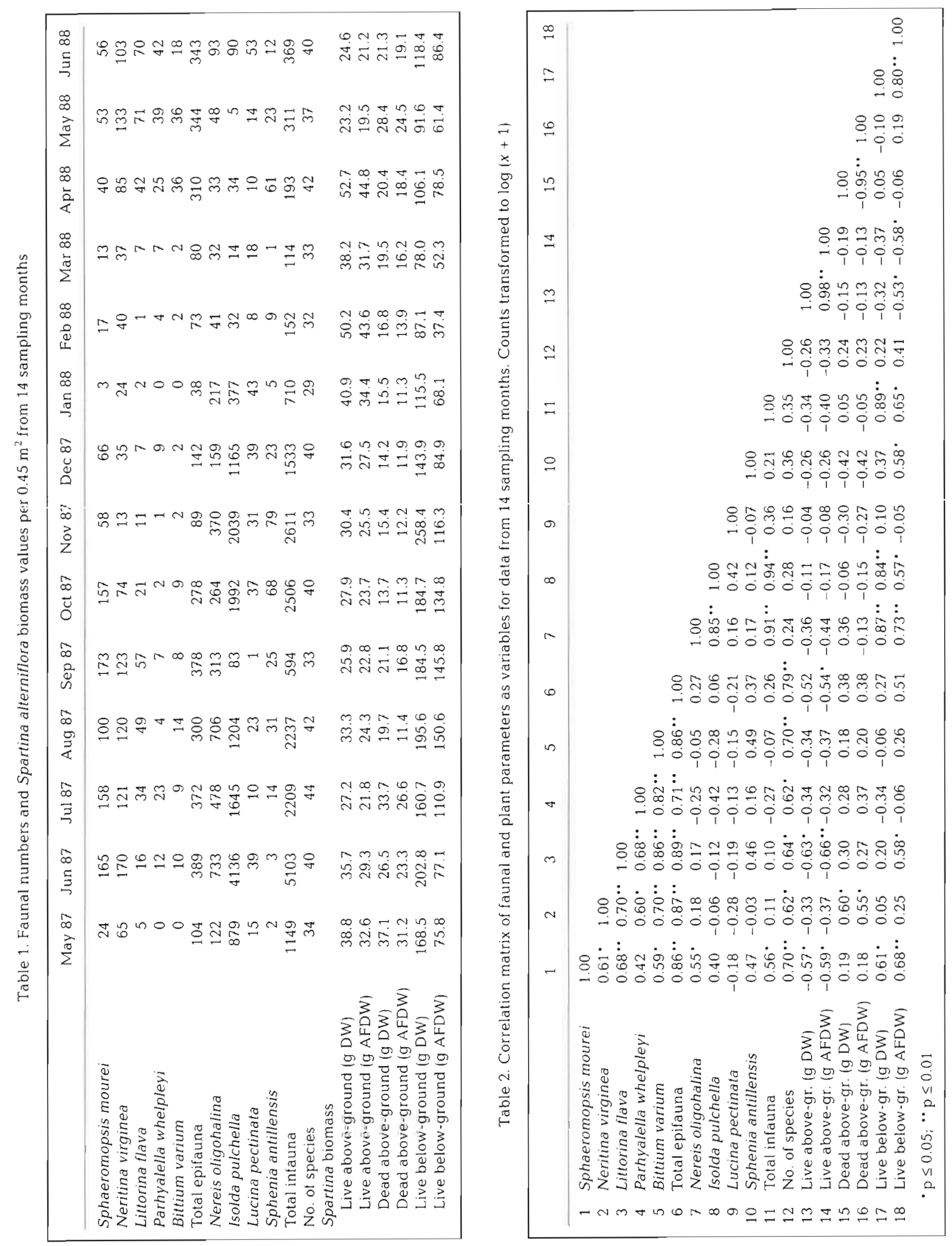
Table 3. Results of stepwise multiple regression analyses, showing the independent variables included in the final fitted model and their statistical significance. Values transformed to $\log (x+1)$. First-order positive autocorrelation rejected by Durbin-Watson test at 0.01 level for all variables. LBG.DRY: live below-ground Spartina biomass, dry weight; LBG.ASH: live below-ground Spartina biomass, ash-free dry weight; LAG.DRY: live above-ground Spartina biomass, dry weight; LAG. ASH: live above-ground Spartina biomass, ash-free dry weight; DAG.DRY dead above-ground Spartina biomass, dry weight; DAG.ASH: dead aboveground Spartina biomass, ash-free dry weight

\begin{tabular}{|c|c|c|c|c|}
\hline $\begin{array}{l}\text { Dependent } \\
\text { variables }\end{array}$ & $\begin{array}{l}\text { Independent } \\
\text { variables }\end{array}$ & $\begin{array}{c}\text { Final regression } \\
\text { coefficient }\end{array}$ & Constant & $\mathrm{R}^{2}$ \\
\hline Sphaeromopsis mourei & LGB.ASH & 1.95 & -2.07 & $0.45 \cdots$ \\
\hline Neritina virginea & DAG.DRY & 1.58 & -0.27 & $0.39^{\circ}$ \\
\hline Littorina flava & LAG.ASH & -3.02 & 5.61 & $0.44 \cdots$ \\
\hline Parhyalella whelpleyi & No variables met criteria & & & \\
\hline Bittium varium & No variables met criteria & & & \\
\hline Total epifauna & LAG.ASH & -1.66 & 4.67 & $0.31^{\bullet}$ \\
\hline Nereis oligohalina & LBG.DRY & 2.66 & -3.51 & $0.76^{\prime} \cdot$ \\
\hline Isolda pulchella & LBG.DRY & 4.91 & -8.12 & 0.71 \\
\hline Lucina pectinata & No variables met criteria & & & \\
\hline Sphenia antillensis & LBG.ASH & 1.86 & -2.44 & $0.35^{\circ}$ \\
\hline Total infauna & LBG.DRY & 2.96 & -3.45 & $0.79^{\cdots}$ \\
\hline No. of species & No variables met criteria & & & \\
\hline$\cdot \mathrm{p} \leq 0.05 ; \cdots \mathrm{p} \leq 0.01$ & & & & \\
\hline
\end{tabular}

flava densities, but with negative final regression coefficients, and $\mathrm{R}^{2}$ lower than 0.45 . The epifaunal species Sphaeromopsis mourei and the infaunal species Sphenia antillensis were better predicted by live below-ground plant biomass as ash-free dry weight (LBG.ASH).

The absence of linear models containing 2 or more independent variables could be attributed to crosscorrelation among independent variables, since correlation coefficients between dry weight and ashfree dry weight biomass values were always strong and significant. However, first order positive autocorrelation was rejected by Durbin-Watson test at 0.01 level for all variables.

In using principal component analysis (PCA) on the $\log (x+1)$ transformed data to examine species relationships, the variable structure could be simplified from 18 variables to only 2 significant components, which still retained a large portion $(65.7 \%)$ of the total variation (Fig. 2).

The first component accounted for $40.2 \%$ of the total variance and represented winter conditions of 1987 (high positive weights), characterized by high epifaunal abundance, high number of species and high densities of some epifaunal species, such as Sphaeromopsis mourei and Littorina flava, opposed to summer conditions of 1988 (high negative weights), associated with high values of live above-ground biomass and low faunal richness and abundance. The second component $(25.5 \%$ of the total variance) further characterized seasonal conditions, with high positive weights for late spring of 1987 (high infaunal abundance, high densities of Isolda pulchella and Nereis oligohalina, and high live below-ground biomass) separated from high negative weights for late autumn/early winter of 1988 (high values of dead above-ground tissue, high densities of Neritina virginea and Bittium varium).

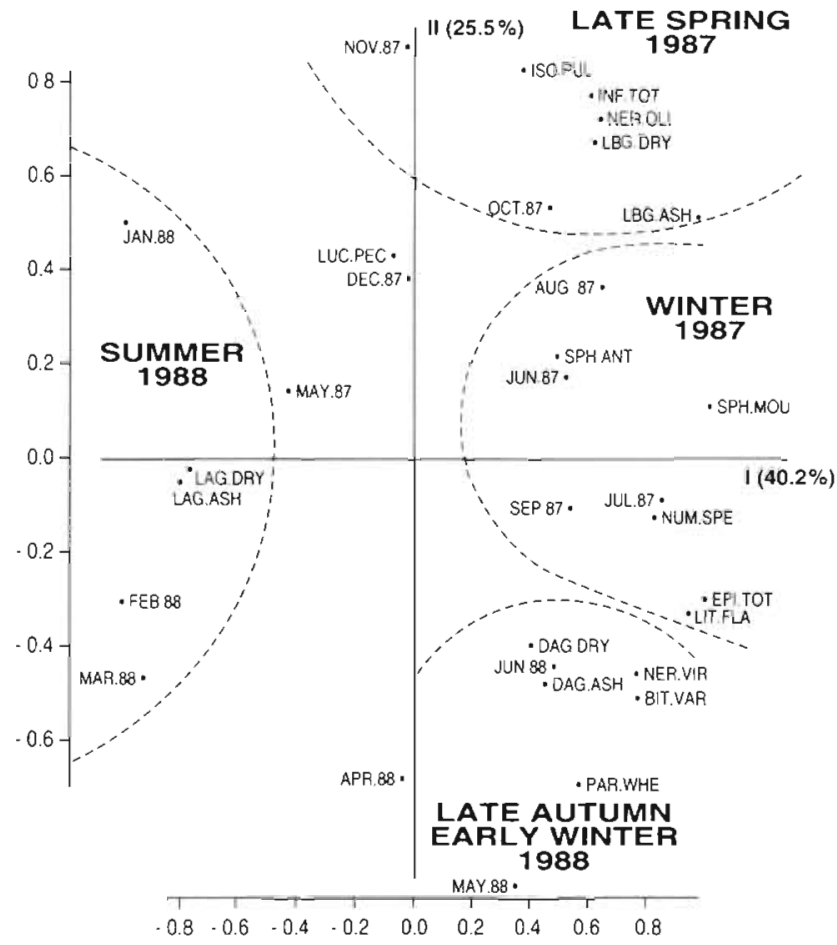

Fig. 2. PCA ordination diagram of faunal parameters, plant biomass values and sampling months on Axes I and II. Codes for variables and sampling months in text 


\section{DISCUSSION}

Seasonal cycles of Spartina growth and decline, similar to those in temperate regions, have been previously described by Lana et al. (1991) for the study area. Below-ground components, such as roots and rhizomes, were characterized by larger biomass in late spring, as a reflection of storage events, while live above-ground biomass was higher during the summer, prior to flowering. The opposing relationship between aerial growth and underground storage was further substantiated by the negative correlation between above- and below-ground biomass values of living tissues. The higher level of dead above-ground material in winter might suggest that mortality rates of Spartina are also higher in this season. The presence of below- or above-ground plant structures, coupled with seasonal fluctuations in detrital input and predation pressure, affect the composition, abundance and persistence of the invertebrate fauna in the local euhaline, high-energy tidal flat (Lana \& Guiss 1991). The interaction between plant cover and time of year has been shown to be an important source of variability for faunal parameters. Knowledge of this interaction is a prerequisite to a useful interpretation of data generated by between-site comparisons or by studies on the temporal variation of local associations (Tararam \& Wakabara 1987, Lana \& Guiss 1991)

No prediction based on above- or below-ground plant biomass could explain the variation in the total number of species. Local species richness thus seems to be be affected by other equally important but poorly investigated biological and physical processes. There is evidence that predation, density-dependent processes, larval settlement patterns and various physical factors (Kneib 1984, Rader 1984) play a major role in the organization of salt marsh benthic communities.

Spartina culms have been shown to play a substantial role in the distribution and abundance patterns of sediment-dwelling invertebrates of the salt marsh (Rader 1984). However, we were unable to detect any significant relationship between infaunal abundance and Spartina aerial biomass. In contrast, total infaunal abundance was clearly associated with live belowground plant biomass as dry weight. Live belowground biomass as ash-free dry weight was not included in the final regression model, suggesting that roots and rhizomes are primarily used either as refugia or as sites for the attachment of tubes but not as a food source. This hypothesis is supported by the following evidence: (1) gut content analyses showed that Isolda pulchella is a detritivore species, and Nereis oligohalina an omnivore species, heavily dependent on detritus, and that they do not feed on Spartina living tissue (pers. obs.); (2) tubes of $I$. pulchella are closely associated with underground Spartina mats. I. pulchella is scarce in nearby unvegetated soft-bottoms, but can reach population densities of 10000 ind. $\mathrm{m}^{-2}$ in local salt marshes and mangroves. The strong and highly significant correlation between the densities of $N$. oligohalina and I. pulchella may imply that these species react in a similar way to seasonal variations of below-ground plant biomass. Capehart \& Hackney (1989) found an inverse relationship between infaunal clam density and the density of plant roots and rhizomes in tidal marshes of North Carolina, USA. Though they did not make a generalization about the importance of marsh plant below-ground biomass to infaunal densities, it was suggested that a negative relationship could be important for a variety of different species. This hypothesis was not supported by our findings; it seems that macrofaunal response to dense plant biomass primarily depends on the feeding and mobility strategies of locally dominant species.

The abundance of another infaunal dominant, Sphenia antillensis, was significantly affected by the presence of live below-ground biomass expressed as ash-íree dry weighi bui nui as dry weight. S. antillensis does not seem to use Spartina mats as a refuge, in contrast to Nereis oligohalina and Isolda pulchella.

Unlike all the other infaunal dominants, the density of Lucina pectinata did not correlate with plant biomass, either as dry weight or ash-free dry weight. A previous study has shown that $L$. pectinata is the only local species to react primarily to variations of sediment organic content (Lana \& Guiss 1991). It is not possible to assess the influence of dead below-ground biomass on this species or on other macrofaunal parameters, due to the lack of data. However, it is quite possible that dead plant material greatly affects the abundance of subsurface detritivore species. In addition, the presence of dense rhizome mats, either live or dead, may prevent predators from gaining access to potential prey species or even impede their burrowing activities (Orth et al. 1984).

Spartina may play a significant role in sediment oxidation, increasing space availability for macrofaunal species. In vegetated sediments, this can occur via air entry in response to water removal by evapotranspiration or drainage (Howes et al. 1986). This could further explain the dense and diversified association of invertebrates at the study site, when compared with adjacent unvegetated areas (Lana \& Guiss 1991).

The diversity and abundance of animal species associated with salt marshes and seagrass meadows have been shown to increase with increasing plant biomass (Heck \& Orth 1980, Orth et al. 1984). Nelson (1979) and Coull \& Wells (1983) hypothesized or showed empirically a threshold level of structural 
complexity for plant cover above which significant protection from predation occurs and faunal numbers increase. However, we found a significant negative relationship between epifaunal abundance and aerial plant biomass values. It is still unclear what is responsible for this unexpected pattern. However, various hypotheses can be proposed: (1) many epifaunal grazers or detritivores feed primarily on microand macroalgae rather than on living macrophyte tissue (Levinton et al. 1984). The low palatability of Spartina and other marine macrophytes has been attributed to the presence of soluble phenolics that may deter feeding (McMillan et al. 1980, Valiela et al. 1984). Thus, living Spartina culms and leaves would be used as physical substrata rather than as a limiting food source and an increase in aerial biomass would not necessarily be followed by a faunal increase; (2) the relative height and leaf orientation of Spartina have been suggested to affect light penetration in salt marsh formations (Pomeroy et al. 1981, Morris 1989). The higher and denser Spartina cover in the summer may decrease light availability and limit the development of algal films on plant blades and soil. In consequence, the densities of grazing or detritivore species, that numerically dominate the epifauna, could be negatively affected. Gallagher \& Daiber (1974) observed an increase in the relative contribution of the algae to the total energy flow during the winter months in a Delaware salt marsh; (3) high levels of aerial biomass in the summer coincide seasonally with low detrital input (Lana et al. 1991) and probably with a decreased food availability for grazers and detritivores; (4) higher predation pressure in the summer can have a direct effect on less motile and more visible epifaunal prey, such as the gastropods Neritina virginea and Littorina flava. Epifauna seem to be more susceptible than infauna to predation by epibenthic predators (Orth et al. 1984, West \& Williams 1986, Frid \& James 1988). On the other hand, dense plant cover in the summer, which may reduce the foraging efficiency of large motile predators (Lin 1989), can provide refuge to intermediate predators, such as polychaetes and nemerteans. This could cause additional pressure on smaller epifaunal prey, in accordance with the 3-level predator-prey model proposed by Ambrose (1984). In fact, Decho et al. (1985) provided some circumstantial evidence that predation pressures on meiofauna are higher in seagrass sediments than in adjacent open sand areas, because a greater number of potential predators reside within the seagrass. Predator-prey interactions in seagrass meadows have been shown to be altered by variations in the shape of leaves or density of shoots (Orth et al. 1984). Although we have not performed any exclusion experiments, our data provide some evidence that epifaunal numbers may be influenced by overall aerial biomass, but in a negative or nonlinear correlationship.

Neritina virginea was the only epifaunal species positively correlated with dead above ground plant biomass, expressed either as dry weight or ash-free dry weight. The feeding biology of $N$. virginea is not well known; however, $N$. reclivata, a closely related species, has been shown to feed on the epidermis of grasses and associated microbiota on Spartina detritus (Day et al. 1973).

The epifaunal species Sphaeromopsis mourei and Littorina flava were strongly correlated with belowground biomass. S. mourei was often found inside the rhizomes, but it is not known if it behaves as a true plant borer or if it utilizes already available crevices. It is not easy to explain such an unexpected pattern for L. flava. During low tides, both L. flava and $N$. virginea can be found in soil crevices just at the interface between culms and below-ground structures (pers. obs.). However, since the percent occurrence of L. flava was very small, any correlative relationships could be artificial or spurious.

The other epifaunal dominants, Parhyalella whelpleyi and Bittium varium, were not influenced by plant biomass, suggesting that other underlying ecological factors have to be taken into account to explain their distribution and abundance patterns. Lower population levels in the summer were probably related to higher predation rates (Lana \& Guiss 1991).

The main conclusions to be drawn from the above quantitative inferences are: (1) infaunal abundance is strongly affected by below ground plant biomass, which provides refuge to organisms or physical support to tubes, but aerial plant biomass does not seem important for the regulation of infaunal numbers; (2) the relationship between species richness as a whole, epifaunal abundance and aerial plant biomass is complex and should be expressed by nonlinear models. Detrital input and predation pressure seem to play, besides plant architecture, a major role in structuring salt marsh epifaunal communities. The sensitivity of several faunal parameters to plant biomass variations indicates the importance of obtaining accurate descriptions of these properties for community studies in salt marshes

Acknowledgements. This work was supported by $\mathrm{CNPq}$ (Brazilian National Research Council) under Grant 301532/84 to Paulo Lana. We are especially grateful for the assistance provided by Sibelle Trevisan Disaró during the first stages of this research. High densities of macrovertebrate colleagues assisted us with field work. We thank Mário Barletta, Ivan Britto, Arno Blankensteyn, José Roberto Botelho, Elenice Gonçalves, Hilda Sovierzoski, and Gisele Sessegolo. Computer facilities for data analyses were provided by Jean 
Valentin and Sérgio Netto. Theresinha de Jesus Absher (Bivalvia and Gastropoda) and Maria Theresa Berardo (Amphipoda) identified part of the invertebrate fauna.

\section{LITERATURE CITED}

Ambrose, W. G. (1984). Role of predatory infauna in structuring marine soft-bottom communities. Mar. Ecol. Prog. Ser. 17: 109-115

Bemvenuti, C. E. (1987). Macrofauna bentônica da regiào estuarial da Lagoa dos Patos, RS, Brasil. Simpósio sobre Ecossistemas da Regiāo Sul e Sudeste Brasileira. Vol. 1. Publicação da Academia de Ciências do Estado de São Paulo 54: 428-459

Capehart, A. A., Hackney, C. T. (1989). The potential role of roots and rhizomes in structuring salt-marsh benthic communities. Estuaries 12: 119-122

Capitoli, R. R., Bemvenuti, C. E., Gianuca, N. M. (1977). Ocorrência e observaçōes bioecológicas do caranguejo Metasesarma rubripes (Rathbun) na região estuarial da Lagoa dos Patos. Atlântica 2: 50-62

Capitoli, R. R., Bemvenuti, C. E., Gianuca, N. M. (1978). Estudos de ecologia bentônica na região estuarial da Lagoa dos Patos. I - As comunidades bentônicas. Atlântica 3: $5-22$

Coull, B. C., Wells, J. B. J. (1983). Refuges from fish predation: experiments with phytal meiofauna from the New Zealand rocky intertidal. Ecology 64: 1599-1609

Daiber, F. C. (1982). Animals of the tidal marsh. Van Nostrand Reinhold Co., New York

Day, J. W. Jr, Smith, W. G., Wagner, P. R., Stowe, W. C. (1973) Community structure and carbon budget of a salt marsh and shallow bay estuarine system in Louisiana. Center for Wetland Research, Louisiana State University. Publ. No LSU-SG-72-04: 1-80

Decho, A. W., Hummon, W. D., Fleeger, J. W. (1985). Meiofauna-sediment interactions around subtropical seagrass sediment using factor analysis. J. mar. Res. 43: 237-255

Fonseca, M. S., Fisher, J. S., Ziemann, J. G., Thayer, G. W. (1982). Influence of the seagrass Zostera marina L. on current flow. Estuar. coast. Shelf Sci. 15: 351-364

Frid, C. L. J., James, R. (1988). The role of epibenthic predators in structuring the marine invertebrate community of a British coastal salt marsh. Neth. J. Sea Res. 22 $307-314$

Gallagher, J. L., Daiber, F. C. (1974). Primary production of edaphic algae communities in a Delaware salt marsh Limnol. Oceanogr 19: 390-395

Gerlach, S. A. (1958). Die Mangroveregion tropischer Küsten als Lebensraum. Z. Morph. Okol. Tiere 46:636-730

Heck, K. L. (1977). Comparative species richness, composition and abundance of invertebrates in Caribbean seagrass (Thalassia testudinum) meadows (Panama). Mar. Biol. 41. $335-348$

Heck, K. L., Orth, R. J. (1980). Seagrass habitats: the roles of habitat complexity, competition and predation in structuring associated fish and motile macroinvertebrate assemblages. In: Kennedy, V. S. (ed.). Estuarine perspectives. Academic Press, New York, p. 449-464

Howes, B. L., Dacey, J. W. H., Goehringer, D. D. (1986). Factors controlling the growth form of Spartina alterni- flora: feedbacks between above-ground production, sediment oxidation, nitrogen and salinity. J. Ecol. 74 : $881-898$

Kneib, R. T. (1984). Patterns of invertebrate distribution and abundance in the intertidal salt marsh: causes and questions. Estuaries 7: 392-412

Knoppers, B. A., Brandini, F. P., Thamm, C. A. (1987). Ecological studies in the Bay of Paranagua. II. Some physical and chemical characteristics. Neritica 2: 1-36

Lana, P. C., Guiss, C., Disaro, S. T (1991). Seasonal variation of biomass and production dynamics for above- and belowground components of a Spartina alterniflora marsh in the euhaline sector of Paranaguá Bay (SE Brazil). Estuar. coast. Shelf Sci. 32: 231-241

Lana, P. C., Guiss, C. (1991). Influence of Spartina alterniflora on the structure and temporal variability of macrobenthic associations in a tidal flat of Paranaguá Bay (Southeastern Brazil). Mar. Ecol. Prog. Ser. 73: 231-244

Legendre, L., Legendre, P. (1983). Numerical ecology. Elsevier Scientific Publishing Co., Amsterdam

Levinton, J. S., Bianchi, T. S., Stewart, S. (1984). What is the role of particulate organic matter in benthic invertebrate nutrition? Bull. mar. Sci. 35: 270-282

Lin, J. (1989). Influence of location in a salt marsh on survivorship of ribbed mussel. Mar. Ecol. Prog. Ser. 56: $105-110$

Long, S. P., Mason, C. F. (1983). Saltmarsh ecology. Blackie and Son, Glasgow

McMillan, C., Zapata, O., Escobar, L. (1980). Sulphated phenolic compounds in seagrasses. Aquat. Bot. 8: 267-278

Morris, J. T (1989). Modelling light distribution within the canopy of the marsh grass Spartina alterniflora as a function of biomass and solar angle. Agric. For. Meteorol. 46: $349-361$

Nelson, W. G. (1979). Experimental studies of selective predation on amphipods: consequences for amphipod distribution and abundance. J. exp. mar. Biol. Ecol. 38: 225-245

Orth, R. J., Heck, K. L., Jr, Montfrans, J. (1984). Faunal communities in seagrass beds: a review of the influence of plant structure and prey characteristics on predator-prey relationships. Estuaries 7: 339-350

Pomeroy, L. R., Darley, W. M. Dunn, E. L., Gallagher, J. L., Haines, E. B., Whitney, D. M. (1981). Primary production. In: Pomeroy, L. R., Wiegert, R. G. (eds.) The ecology of a salt marsh. Springer-Verlag, New York, p. 39-67

Rader, D. N. (1984). Salt marsh benthic invertebrates: smallscale patterns of distribution and abundance. Estuaries 7 : $413-420$

Ranwell, D. S. (1972). Ecology of salt marshes and sand dunes. Chapman and Hall, London

Takeda, A. M. (1988). Estrutura de associaçōes macrobênticas da Spartina alterniflora Loiseleur, 1807 no complexo estuarino-lagunar de Cananéia. Doctoral thesis. Oceanographic Institute, Säo Paulo University

Tararam, A. S., Wakabara, Y (1987). Benthic fauna living on Spartina alterniflora of Cananéia estuarine region (25 02 'S -47 56' W). Bolm Inst. Oceanogr., S Paulo 35: 103-113

Valiela, I., Wilson, J., Buchsbaum, R., Rietsma, C., Bryant, D., Foreman, K., Teal, J. (1984). Importance of chemical composition of salt marsh litter on decay rates and feeding by detritivores. Bull. mar. Sci. 35: 261-269

West, D. L., Williams, A. H. (1986). Predation by Callinectes sapidus (Rathbun) within Spartina alterniflora (Loisel) marshes. J. exp. mar. Biol. Ecol. 100: 75-95 